\title{
La metáfora como recurso epistémico en EI príncipe de Nicolás Maquiavelo
}

\author{
Christian Nuñez \\ Universidad del Valle, Colombia \\ Luis Felipe Barrera \\ Alcaldía de Cali, Colombia
}

(c) $\underset{\mathrm{gr}}{(1)}$ 


\title{
La metáfora como recurso epistémico en El príncipe de Nicolás Maquiavelo
}

\begin{abstract}
Resumen: en esta investigación, pretendemos responder al problema de cómo Maquiavelo recurre a la metáfora para aumentar y transmitir fórmulas de acción que simplifiquen los conceptos del mundo político para hacerlos aplicables en la realidad política; esto, teniendo en cuenta que la metáfora tiene como función esencial permitir la comprensión de un conceptoproblema político a través de otro que no pertenece al mundo político, lo que generaría nuevas formas de intervenir en él. Nuestra tesis es que la metáfora juega un papel importante en la argumentación en El Príncipe porque no es simplemente un adorno del discurso, sino un recurso fundamental para aumentar y transmitir un saber práctico sobre la realidad política.
\end{abstract}

Palabras Clave: Maquiavelo, Metáfora, acción política, Ricœur, figuras del discurso.

\section{The metaphor as an epistemic resource in Machiavelli's The prince}

\begin{abstract}
Machiavelli uses metaphors to increase and spread principles of action that simplify the concepts of the political world to make them applicable in political reality; this takes into account the idea that metaphor has as an essential function the understanding of a concept-political problem through another that does not belong to the political sphere, which generates new ways to act in it. Our thesis is that the metaphor plays an important role in the argumentation in The Prince, it is not simply an ornament of the speech, but a fundamental resource to increase and transmit practical knowledge about political reality.
\end{abstract}

Keywords: Machiavelli, Metaphor, political action, Ricœur, speech tropes.

Fecha de recepción: 27 de enero de 2017

Fecha de aceptación: 19 de junio de 2017

Forma de citar (APA): Núñez Prado, C. y Barrera Narváez, L. (2017). La metáfora como recurso epistémico en El príncipe de Nicolás Maquiavelo. Revista Filosofía UIS, 16(2), doi: http://dx.doi. org/10.18273/revfil.v16n2-2017002

Forma de citar (Harvard): Núñez Prado, C. y Barrera Narváez, L. (2017). La metáfora como recurso epistémico en El príncipe de Nicolás Maquiavelo. Revista Filosofía UIS, 16(2), 43-74.

Christian David Núñez Prado: colombiano. Politólogo, Universidad Javeriana de Cali. Magíster en filosofía, Universidad Del Valle. Asociado al grupo de investigación Praxis de la Universidad del Valle enfocado en Ética y Filosofía Política. Líneas de investigación: filosofía de la imaginación, relación estética y política en Carl Schmitt. Asociación Mundial de Ciencia Política (IPSA).

Correo electrónico: christiandnp@gmail.com

Luis Felipe Barrera Narváez: colombiano. Politólogo con estudios en filosofía política. Universidad Javeriana de Cali. Analista político en medios de comunicación y asesor de la Alcaldía de Santiago de Cali.

Correo electrónico: luisfebarreracali@gmail.com

\footnotetext{
* Artículo de reflexión derivado de investigación. Agradecemos al profesor Jorge López del departamento de Ciencia Política en la Universidad Javeriana Cali, por su dirección y apoyo en la realización de este artículo.
} 


\section{La metáfora como recurso epistémico en El príncipe de Nicolás Maquiavelo}

\section{Introducción}

Entre la pluralidad de autores que han interpretado El Príncipe de Nicolás Maquiavelo ${ }^{1}$ hay un grupo de comentaristas que comprendieron su obra como una serie de pautas orientadas hacia la acción política. En estos autores se advierte una característica compartida, la cual consiste en asumir que los argumentos expuestos en El Príncipe están encaminados a proponer una serie de fórmulas con el fin instruir a un gobernante para llevar a cabo una acción política eficaz ${ }^{2}$. Sin embargo, estos autores han hecho énfasis en distintos aspectos de la argumentación de Maquiavelo para sostener esta tesis ${ }^{3}$. Esta investigación propone un énfasis nuevo para seguir afirmando que la obra maquiaveliana propone una serie de pautas que orientan la acción política, pero a partir del uso argumentativo de la metáfora en El Príncipe.

\footnotetext{
${ }^{1}$ El estudio introductorio del profesor Rafael del Águila nos da una muestra de la pluralidad de interpretaciones que se han elaborado sobre Maquiavelo y su obra. Por ejemplo, Schmitt, Sabine, Olschki y Cassirer concibieron a Maquiavelo como un científico devoto del empirismo, mientras que, por otro lado, Bukhardt y Meinecke lo retratan como un esteta de la política. Rivadeneira, Saavedra Fajardo y Campanella condenaron la obra de Maquiavelo por su supuesto contenido herético. Spinoza, Rousseau, Pocock, Skinner y Viroli interpretaron al pensador florentino como un republicano tenaz. Del Águila, R. (2006). Ernst Cassirer, Max Horkheimer y Luciana Samamé, autores con los que trabajamos en este ensayo están inscritos en esta corriente.

2 Para profundizar el tema de la eficacia en Maquiavelo ver: Camou, A. (2001); Chevallier, J.J. (1970).

${ }^{3}$ Entre los estudios que abordaremos en esta investigación, podemos indicar que el de Luciana Samamé realiza un énfasis en la historia como recurso útil para la acción política, mientras que Horkheimer y Cassirer destacan las constantes de la naturaleza humana que permiten la previsión para la acción política.
} 
Para introducir nuestra propuesta, primero debemos precisar cómo puede ser reconocida la obra maquiaveliana como una apuesta teórica que propone una serie de reglas generales que orientan la acción política. Para empezar, Ernst Cassirer y Max Horkheimer son dos de los autores que suscribimos en la corriente de intérpretes que asumen El Príncipe como un tipo de conocimiento destinado a orientar la acción política. Tanto Cassirer como Horkheimer afirmaron que desde las regularidades de "las pasiones" y "los deseos", es posible establecer parámetros para la actividad política debido a que existen ciertas constantes que permanecen en la historia de la humanidad. Bajo esta interpretación, la acción política se arraiga en una concepción de la naturaleza humana estable ${ }^{4}$, que se vale de las constantes históricas para posicionarse frente a la imprevisibilidad del resultado de las acciones humanas. Para estos dos autores, Maquiavelo propone una ciencia de la política cuyo producto es un conocimiento que postula enunciados generales sobre la acción política.

De las lecturas de Horkheimer y Cassirer es posible deducir lo siguiente: Si dicha naturaleza humana se caracteriza por sus constantes pese al paso de los siglos, la historia puede tener un valor práctico para guiar las acciones de los hombres. Los sucesos del pasado servirían para orientar las acciones del presente pues el pasado sirve de faro ante la incertidumbre de los desafíos futuros. Esta lectura es corroborada por Luciana Samamé con el desarrollo del concepto de historia en Maquiavelo como "magistra vitae". La autora afirma que la noción de historia adoptada por Maquiavelo en su obra es concebida como una maestra porque la historia imparte conocimiento útil para la intervención política. La historia permite sugerir pautas de acción que resultaron exitosas o rehuir de las que fracasaron en el pasado. La historia no es solo una disciplina de carácter cognitivo o una actividad placentera ${ }^{5}$, sino una herramienta cuya utilidad permite orientar la acción política, en la medida en que genera conocimiento dirigido a garantizar la acción política certera.

A partir de esta corriente de interpretación de El Príncipe, desarrollamos nuestra propuesta y para ello recuperamos de las lecturas de Cassirer y Horkheimer con el propósito de ubicar en la obra de Maquiavelo el desarrollo de un conocimiento con estatus científico, lo que supone el carácter empírico, sólido, predictivo, comunicable y regulativo de dicho "conocimiento". Sin embargo, afirmamos que

\footnotetext{
${ }^{4}$ Sobre el concepto de naturaleza humana, es preciso aclarar que ni Maquiavelo o los intérpretes aquí mencionados hacen un desarrollo minucioso del término en consonancia con la amplitud que indicaría. Sin embargo, sí lo utilizan reiteradamente para dar cuenta de las regularidades de las "pasiones" y "deseos" que, según interpretan en Maquiavelo, sí permanecen constantes y permiten la emergencia de una ciencia de la política.

${ }^{5}$ La historia para Maquiavelo sí permite desarrollar conocimiento, pero no por el conocimiento mismo como muchos humanistas de su época creían. El objetivo de estudiar historia para Maquiavelo, es porque resulta útil para discernir la acción política más eficaz como veremos más adelante.
} 
las interpretaciones de Samamé, Cassirer y Horkheimer, están muy ajustadas a la postulación de los enunciados generales que posibilitan el "conocimiento" y la acción política; es probable que su lectura positivista haya advertido otros matices de la propuesta maquiaveliana.

En la argumentación de El Príncipe identificamos un uso amplio de figuras retóricas, entre ellas la metáfora, cuyo uso ha sido asociado más al campo literario que al de la ciencia ${ }^{6}$, algo que resulta paradójico pues ¿cómo es posible que la obra de Maquiavelo pueda ser interpretada como un escrito de pretensiones científicas, como afirma Cassirer y Horkheimer, cuando en realidad su argumentación está colmada de figuras literarias, particularmente de metáforas? Por otro lado, ¿sería posible reconocer a partir de las metáforas presentes en El Príncipe la transmisión de una serie de pautas orientativas de la acción política?

Ante los interrogantes anteriores, sostenemos en esta investigación que las interpretaciones como las de Cassirer, Horkheimer y Samamé, no se detienen en la cuestión metafórica y por tanto pueden complementarse con los comentarios de Marie Gaillé sobre la imaginación práctica en Maquiavelo. En su estudio sobre el pensador florentino, Gaillé hace un breve comentario sobre la forma en que Maquiavelo utiliza la imaginación para recrear la experiencia cercana, reconstruir la historia y planear posibles escenarios de acción mediante la anticipación. Gaillé anuncia, aunque no desarrolla con profundidad la noción de imaginación como facultad que posibilita la acción política.

Nuestro interés es recuperar este comentario de Gaillé sobre la imaginación y ampliarlo con la teoría de la metáfora de Paul Ricœur. Partimos desde la metáfora como una de las figuras del discurso que más abundan en El Príncipe para dar cuenta de esta nueva propuesta. Para Ricœur, la metáfora no es simplemente un adorno

\footnotetext{
Como manifiesta Héctor A. Palma (desde su apuesta por una reivindicación de la metáfora en las ciencias, "habitualmente se afirma que las metáforas son expresiones en las cuales se dice algo, pero se evoca o sugiere otra cosa, que son -o deberían ser- patrimonio casi exclusivo del lenguaje literario o del lenguaje vulgar, y que no son relevantes en el discurso científico" (2005, p. 47). Sin embargo, Palma considera que se puede discrepar de este punto de vista y sostener, por el contrario, "que es fructífero en epistemología considerar que las metáforas dicen algo por sí mismas y no como meras subsidiarias de otra expresión considerada literal; que, aunque hay excelentes ejemplos en la literatura, también hay metáforas brillantes y fecundas en la ciencia y, la tesis más fuerte, que las metáforas cumplen en la ciencia un papel constitutivo fundamental" (47). Palma sostiene estas observaciones con los ejemplos de metáforas científicas como: el universo es un organismo, o bien que es una máquina, o que es un libro escrito en caracteres matemáticos; que las leyes de la economía o la sociología son equivalentes a las de la física newtoniana; que entre los pueblos y culturas operan mecanismos de selección de tipo darwiniano, etc. La investigación de Palma (2005) sostiene que en infinidad de ocasiones las metáforas utilizadas resultan genuinos intentos de descripción y/o explicación acerca del mundo; para ampliar el tema de la tensión entre metáfora y ciencia recomendamos la propuesta epistemológica de este autor.
} 
del discurso, un recurso estético, sino un insumo fundamental para aumentar el conocimiento de la realidad y, en la medida en que la metáfora posibilita la relación con el mundo, es orientativa de la acción humana. En El Príncipe encontramos varias metáforas como la metáfora pictórica de la dedicatoria, la de la tisis, la de la fortuna como río o mujer, la del zorro y el león, la del arco y la flecha, la de la armadura, entre otras. Con la metáfora se recurre a la imaginación para "ver un objeto en términos de otro", para comprender un concepto propio de un campo del saber a través de otro que no pertenece a dicho campo, enriqueciendo así la comprensión de un problema o concepto a través del recurso metafórico. En esta investigación emprenderemos un camino hermenéutico para demostrar la función epistémica de la metáfora en la argumentación de El Príncipe.

En esta investigación pretendemos responder al problema de cómo Maquiavelo recurre a la metáfora para aumentar y transmitir fórmulas de acción que simplifiquen los conceptos del mundo político para hacerlos aplicables en la realidad política; esto teniendo en cuenta que la metáfora tiene como función esencial de permitir la comprensión de un concepto-problema político a través de otro que no pertenece al mundo político, lo que generaría nuevas formas de intervenir en él. Para resolver el problema planteado, recurriremos primero a la noción de la historia como magistra vitae la cual nos permitirá identificar la forma en que el pensador florentino infiere la utilidad práctica de ciertos acontecimientos históricos. Para comprender esta noción de la historia es necesario reconocer los aportes de Max Horkheimer y Ernst Cassirer los cuales sugieren que Maquiavelo propuso una "ciencia de la política" basada en las regularidades históricas de la naturaleza humana, facilitando la acción política desde bases conceptuales sólidas. Posteriormente, retomamos los comentarios de Mary Gaillé sobre la imaginación práctica en Maquiavelo y los ampliaremos con el uso de la imaginación según Paul Ricœur, la cual será el eje de nuestra exploración. Con estos insumos teóricos abordaremos el análisis de tres metáforas presentes en El Príncipe con las cuales demostraremos su función en la argumentación maquiaveliana. Nuestra tesis es que la metáfora juega un papel importante en la argumentación en El Príncipe porque no es simplemente un adorno del discurso, sino un recurso fundamental para aumentar y transmitir un saber práctico sobre la realidad política.

\section{Los cimientos del mundo político. Las claves de la orientación práctica en la arena política}

\subsection{La historia como magistra vitae}

El primer paso para reconocer la orientación práctica de los escritos maquiavelianos, es tomar los planteamientos de algunos autores que comparten esta visión sobre la obra del pensador florentino. Los pensadores que presentamos como pertenecientes a esta corriente de interpretación son L. Samamé, E. Cassirer 
y M. Horkheimer ${ }^{7}$. Veamos primero cómo desde la interpretación propuesta por Luciana Samamé sobre el concepto de historia como "magistra vitae" en Maquiavelo, es posible reconocer la orientación práctica de las inferencias propuestas por el pensador florentino sobre los hechos del pasado.

Tal vez el aspecto en el que más se pueda reconocer en la obra de Maquiavelo una apuesta por el conocimiento útil y que oriente la acción política, es en el trato que el pensador florentino otorga a la historia. Según Samamé, la historia en Maquiavelo cobra la forma de una "pedagogía política" cuyo valor radica en su utilidad más que en una búsqueda objetiva por los hechos del pasado. Para Samamé "Maquiavelo busca en el pasado, en la Antigüedad clásica, un modelo, o al menos una pista, para encauzar el presente" (2010, p. 125). En este sentido, Maquiavelo sigue ligado a las aspiraciones del humanismo cívico del renacimiento que procura recuperar las máximas grecolatinas para orientar el presente.

Preocupado por las disputas políticas en la Italia de su época, expresadas en las luchas entre ciudades y facciones al interior de las ciudades, el pensador florentino encuentra en la experiencia de los antiguos una guía para la acción política segura. Esta búsqueda de bases sólidas para dirigir la acción ya estaba vigente en el humanismo cívico de la época, como comentó Skinner (2008) (citado por Samamé, 2010), porque "los dos dogmas fundamentales de la historiografía humanista eran que las obras históricas debían inculcar lecciones morales, y que sus materiales debían por tanto seleccionarse y organizarse de manera que ofrecieren las lecciones adecuadas con la máxima intensidad" (p.100). La historia como un estudio de suma importancia en la tradición humanista también está destinada a orientar la acción política, así como la retórica estaba encauzada a definir el mejor curso para las acciones políticas por parte de los regentes de las ciudades de la bota itálica. Al fin y al cabo, tanto la historia como la retórica eran materias fundamentales en el currículo de estudios humanistas ${ }^{8}$.

\footnotetext{
Hay que aclarar que estos autores, particularmente Ernst Cassirer y Max Horkheimer, exponen estas observaciones sobre Maquiavelo, para luego pasar a criticarlas. Ambos rechazan la postulación científica de los escritos del pensador florentino, aunque reivindican la lectura positivista como la más adecuada a la intención del autor. Intentan aclarar la obra de Maquiavelo para luego atacarla. En esta investigación tampoco aceptamos el análisis de Maquiavelo como un científico de la política que defienden estos intérpretes, solo son utilizados para reconocer una línea de interpretación sobre el pensamiento maquiaveliano que reafirma el carácter práctico de su doctrina.

${ }^{8}$ La formación humanista de Maquiavelo viene desde su infancia. Según Mauricio Viroli, "Los Maquiavelo no podían permitirse confiar a sus hijos a grandes preceptores que hicieran de ellos doctos humanistas. Sin embargo, dieron a Nicolás y a Totto una buena educación que abarcaba el conocimiento del latín, de la gramática y del ábaco, y casi con toda probabilidad, a juzgar de los libros que tenían en casa, también de retórica, o sea del arte de hablar y escribir de manera elocuente, de convencer, persuadir y conmover a quien escucha o lee". (2000, p.22). También se reconoce que los Maquiavelo tuvieron un contacto fluido con la élite intelectual de Florencia. El padre de Nicolás, Bernardo, es representado en un texto de 1483 escrito por Bortolomeo Scala, como un férreo defensor
} 
Por todo lo anterior, la interpretación que hace Samamé de Maquiavelo señala que "el conocimiento histórico tiene una finalidad meramente operativa: es valorado en cuanto nos provea de alguna direccionalidad hacia la cual encaminar nuestras acciones" (Samamé, 2010, p. 125). Maquiavelo hace hincapié en la historia política porque lo que le interesa es fundamentar sus recomendaciones políticas mediante la referencia a hechos históricos sobresalientes ${ }^{9}$, que se destaquen por su ruina o gloria. Maquiavelo acude a lo que Nietzsche denominó la "historia monumental" que no es otra cosa que la revisión episódica de los acontecimientos del pasado soslayando una perspectiva lineal o consecutiva de la historia. A esta noción del pasado solo le interesa dar cuenta de aquellos personajes y acontecimientos que son abordados como "islas" independientes, para tomar de ellos su utilidad paradigmática. Maquiavelo fortalece sus argumentos con las "aparentes" acciones heroicas llevadas a cabo por los grandes protagonistas de la antigüedad, como Rómulo, Licurgo, Moisés, Alejandro Magno, entre otros. En definitiva, a Maquiavelo lo que le interesa es tomar de la historia aquellas enseñanzas que le permitan realizar inferencias de los hechos para luego encausar con éxito la acción política en el presente.

La anterior concepción de la historia en Maquiavelo, presume una noción particular de la naturaleza humana. A partir de las interpretaciones de Ernst Cassirer y Max Horkheimer sobre Maquiavelo, observaremos la forma en que estos autores conciben el tratamiento que Maquiavelo otorga a las pasiones y deseos humanos como elementos que permiten inferir reglas generales y formular un conocimiento científico de la política; aunque ambos autores luego pasen a criticar el modelo científico maquiaveliano. No obstante, este giro crítico de Cassirer y Horkheimer, nuestra intención es retomar sus afirmaciones sobre el carácter cognitivo de la obra de Maquiavelo y como ésta interpretación permite la reducción de posibilidades para la acción política dado el carácter nomotético de las afirmaciones maquiavelianas.

\footnotetext{
de la vida republicana y el respeto de la ley. Scala fue canciller de la república florentina Del Águila, (2006). También se sabe por el libro de registros que llevaba celosamente Bernardo Maquiavelo, el padre de Nicolás, pues este documento permite observar que cuando Nicolás estaba pequeño en la casa de los Maquiavelo habían obras de Cicerón que eran del estudiadas con pasión por los humanistas como las Filípicas, De la formación del orador, De los deberes. La historia de Tito Livio también estaba entre los libros de la familia Maquiavelo. De Gracia. (1994).

${ }^{9}$ Hay que aclarar que estos autores, particularmente Ernst Cassirer y Max Horkheimer, exponen estas observaciones sobre Maquiavelo, para luego pasar a criticarlas. Ambos rechazan la postulación científica de los escritos del pensador florentino, aunque reivindican la lectura positivista como la más adecuada a la intención del autor. Intentan aclarar la obra de Maquiavelo para luego atacarla. En esta investigación tampoco aceptamos el análisis de Maquiavelo como un científico de la política que defienden estos intérpretes, solo son utilizados para reconocer una línea de interpretación sobre el pensamiento maquiaveliano que reafirma el carácter práctico de su doctrina.
} 


\subsection{La ciencia de la política}

Para comprender la concepción de naturaleza humana que subyace a la noción de historia de Maquiavelo, hay que reconocer que él ya hace parte de la historia de las ideas políticas. Por ello hay que diferenciar entre cuál es el concepto de historia que Maquiavelo forjó y por otro lado cuál es el tipo de acercamiento a la obra de Maquiavelo en la historia de las ideas políticas. En el segundo sentido, Ernst Cassirer en su obra El mito del Estado (1946) sostiene que asumir que El Príncipe debe ser comprendido en su contexto histórico, es decir, desde un enfoque estrictamente historicista, es inútil, pues sería imponer los criterios históricos de nuestra época a otra que se encuentra remota en el pasado. El criterio de historia en el siglo XX se caracteriza por la individualización de los hechos y la desconfianza a emitir juicios generales. Sin embargo, ésta no era la condición de los hombres renacentistas pues, según Cassirer, los humanistas del renacimiento creían en la posibilidad de alcanzar la belleza absoluta o la excelencia plena en cualquier arte. Los humanistas del renacimiento eran proclives a forjar ideales basados en la época clásica acerca de la retórica, la arquitectura, la escultura, en definitiva, en todas las ramas del saber.

Para Cassirer ${ }^{10}$, Maquiavelo estaba más preocupado por las constantes en la historia que por los cambios de la misma. La anterior afirmación de Cassirer se basa en varias citas de Los discursos (1512), como por ejemplo, cuando Maquiavelo comenta: "como quiera que estos acontecimientos los producen los hombres, cuyas pasiones y disposiciones permanecen iguales en todas las edades, originan naturalmente los mismos efectos" (2004, p.151). La lectura de Cassirer sobre Maquiavelo sugiere, además, que los sucesos históricos son intercambiables, de aquí que Maquiavelo intercale en su argumentación los ejemplos de la antigua Roma con los de su época. Es esta interpretación, la de tomar casos particulares e inferir su lógica para emitir enunciados generales lo que permite el surgimiento de una ciencia de la política ${ }^{11}$. Por lo tanto, según Cassirer, El Príncipe es un libro que sugiere pautas de acción política permanentes en el tiempo, no un tratado moral, porque indica lo que es útil e inútil, señala lo que tiene que hacer el

\footnotetext{
10 A Maquiavelo, según la lectura de Marie Gaille, más que puntos de vista definitivos en política, le interesa transmitir un conocimiento que procure acercarse a un fenómeno político desde diferentes perspectivas pues la naturaleza de este saber siempre está en construcción. Sin embargo, para el objetivo de nuestra investigación nos interesa retomar la argumentación de Cassirer que del todo no es errada. Nuestra diferencia está en el nivel al que lleva tales afirmaciones.

11 A decir verdad, Cassirer es muy tajante con sus afirmaciones sobre el poder de la deducción lógica. Cassirer comprende a El Príncipe casi como un "recetario" para ejercer el poder político, soslayando el carácter imprevisible de la acción humana y el influjo de lo que Maquiavelo denomina "fortuna" en los planes y acciones de los hombres. Todo esto a pesar de que Cassirer comenta el tema de la fortuna, de nuevo le endilga a Maquiavelo una confianza en el racionalismo para advertir que se puede contener la imprevisibilidad de la fortuna.
} 
gobernante, pues constituye un conocimiento definitivamente práctico. Para Cassirer, Maquiavelo es un técnico de la política. Sin esta perspectiva, todo saber sobre la política sería inestable y por tanto efímero, muy difícil de comunicar y, por tanto, de ser orientativo de las acciones políticas de los sujetos.

La lectura de Cassirer tiene varios aspectos en común con la de Max Horkheimer especialmente en su obra: Historia, metafísica y escepticismo (1968). Según el filósofo de la Escuela de Frankfurt, en el renacimiento se dispusieron las bases de la ciencia natural contemporánea basada en la detección de regularidades en la naturaleza a través de la experiencia y la organización sistemática de la información vía enunciados nomotéticos. Para Horkheimer, a partir de tal conocimiento es posible identificar el carácter predictivo de las ciencias naturales que posibilitan la dominación del hombre sobre la naturaleza. La convicción de que existe una cierta uniformidad en el curso de la naturaleza, es un supuesto propio de la ciencia moderna. Esto significa que para establecer un conocimiento científico, un enunciado general que descubra la regularidad entre diversos fenómenos, este tiene que corroborarse varias veces a través de la experimentación; a partir de ahí es posible la predicción. Pese a lo anterior, las sociedades no solo ejercen dominio sobre la naturaleza, según Horkheimer, los hombres también dominan a otros hombres y los métodos que conducen a la dominación y las reglas que permiten tal dominación es la política. Para Horkheimer, Maquiavelo fue el primero en reconocer esta premisa en el umbral de la modernidad, además de ser el primer pensador en aplicar el método científico a la política.

La interpretación que hace Horkheimer de Maquiavelo permite reconocer que, al existir siempre las mismas regularidades en la historia de la humanidad, (por ejemplo, que siempre existirá el deseo de dominar por parte de unos hombres y el deseo de no ser oprimido por parte de los más) o que dada una serie de condiciones determinadas $X$, es muy probable que se siga un acontecimiento Z. De esta forma, para Horkheimer, esta idea es la que permite el surgimiento de una ciencia de la política, porque debido a las regularidades de la naturaleza humana es posible comunicar enunciados generales que se descubren a través de la historia y que orientan las acciones políticas futuras. Son las pasiones e instintos de los hombres los que determinan el curso de las acciones, pues siempre presentan las mismas características, lo que hace posible determinar el curso de las acciones humanas, pues como afirma Horkheimer "las fuerzas anímicas de base deberán seguir siendo, en esencia, las mismas en toda época; se las concibe de forma a-histórica, lo mismo que las diferentes fuerzas de la naturaleza ${ }^{12 "}$ (1995, p.

\footnotetext{
${ }^{12}$ Esta es la lectura que Horkheimer hace de Maquiavelo aunque posteriormente pase a criticarla. En este punto, tanto Horkheimer como Cassirer reconocen la cientificidad de los escritos de Maquiavelo. Sin embargo, ambos autores reconocen el rol de la fortuna como un aparente obstáculo a las pretensiones de cientificidad que le adjudica a los argumentos de El Príncipe. Sin embargo, toma la misma alternativa de Cassirer pues ambos asumen una confianza amplia en la razón humana. Esta puede combatir los azares de la fortuna, tanto
} 
37). Desde estas regularidades humanas y las inferencias que el "científico de la política" realiza que es posible llevar a cabo predicciones que orienten la acción política.

\section{Imaginación práctica}

Como vimos anteriormente, la noción de la historia en Maquiavelo como magistra vitae interpretada por Samamé, nos ilustró acerca de la forma en que el pensador florentino se acerca a la historia para inferir pautas de acción política sobre los hechos del pasado. Tanto Marie Gaillé como Luciana Samamé coinciden en que Maquiavelo otorga a la historia un trato "maleable" a sus intenciones argumentativas. Sin embargo, Gaillé ofrece un elemento novedoso al describir el procedimiento al que recurre el secretario florentino para aproximarse a la experiencia. Esta nueva perspectiva introduce el concepto de imaginación en esta investigación, permitirá introducir nuestra propuesta, pues Gaillé reconoce con Samamé, Horkheimer y Cassirer, el carácter práctico de la obra maquiaveliana, la diferencia en este punto radica en que Gaillé recurre a la imaginación y no a las regularidades de la naturaleza humana para sustentar sus anotaciones sobre el pensamiento de Maquiavelo. Esta apelación a la imaginación que hace Gaillé, nos servirá de puente entre la posibilidad de afirmar la orientación práctica de la obra maquiaveliana y la teoría de la metáfora.

Veamos qué es lo novedoso que nos sugiere Gaillé sobre la imaginación en Maquiavelo. Para Gaillé (2011), el saber que Maquiavelo propone sobre la política proviene de dos fuentes, la historia y la experiencia. Esto está claramente expresado en la dedicatoria de El Príncipe cuando Maquiavelo afirma que entrega a Lorenzo "el conocimiento de las acciones de los grandes hombres, adquirido por mí mediante una larga experiencia de las cosas modernas y una continuada lectura de los antiguos" (1998, p.33). No obstante, el trato que hace Maquiavelo a la "historia monumental" e "insular" como vimos en Samamé, es similar al otorgado a la historia más cercana a su época y que el pensador florentino llama experiencia. La historia en Maquiavelo no es más que la experiencia de los antiguos, de aquellos "grandes hombres" que vivieron hace miles de años y destacan por sus acciones heroicas. La experiencia por otro lado, son hechos del pasado también, pero de tiempos más recientes y que en gran medida ocurrieron durante la vida del pensador florentino. Es por ello que tanto la historia como la experiencia, en esencia, concurren en la misma senda por medio de la cual Maquiavelo realizará sus inferencias políticas.

en la naturaleza material como en la vida política. El hombre que se destaque por su virtù puede conducir sus acciones exitosamente aunque la fortuna haya intentado desviar sus planes haciendo confusa su situación. 
El primer punto en el que coinciden la historia con la experiencia, es en la forma en que son utilizadas por Maquiavelo para respaldar sus recomendaciones políticas; tanto la historia como la experiencia contemporánea, son expuestas mediante en el ejemplo. Lo importante aquí, y de lo que Gaillé nos advierte, es de la propiedad del ejemplo en la legitimación de las propuestas que hace Maquiavelo, pues el ejemplo no sería tanto una aproximación a la materia concreta de un hecho pasado, sino el lugar mismo de la explicación y demostración de sus ideas. Esto significa que el ejemplo más que presentar una evidencia objetiva del pasado (como vimos en Samamé), es el lugar en el que Maquiavelo forja su pensamiento. Maquiavelo respalda su propuesta sobre un problema político, tanto con ejemplos antiguos como con ejemplos de su experiencia cercana.

El segundo punto en el que coinciden la aproximación maquiaveliana hacia la historia y la experiencia cercana, es el que más nos interesa resaltar aquí, porque para acercarse a la experiencia Maquiavelo recurre a la imaginación. La aclaración que hace Gaillé (2011) sobre la experiencia en Maquiavelo, consiste en que la experiencia está "filtrada" y "transformada" en función de la necesidad argumentativa de Maquiavelo. Cuando realiza una inferencia acerca de un acontecimiento, recurre a la imaginación a la hora de trazar los rasgos del acontecimiento o personaje que toma para reforzar su pauta de acción política. Según Gaillé (2011), Maquiavelo nos ofrece con El Príncipe, una forma de analizar un problema, un actor o una coyuntura política más que pretender un conocimiento objetivo y absoluto sobre un problema político como interpretaron Cassirer y Horkheimer.

Con la aproximación a la experiencia (antigua o contemporánea) Maquiavelo acude a la imaginación para "reconstruir la realidad," y recrear lo que advirtió en sus lecturas sobre la historia o en sus observaciones desde la cancillería florentina. Para Gaillé, la manera con la que Maquiavelo trata la historia antigua o reciente indica que "compartía con León Batista Alberti la convicción de que la imaginación debe intervenir en el informe sobre la realidad para producir un efecto de realidad más eficaz que un calco de la realidad ${ }^{13 "}$ (2011, pp.105-106). De aquí que la forma de acercarse a la experiencia por parte de Maquiavelo según Gaillé "es el fruto de una voluntad de representar la realidad y de la aguda conciencia de que esta representación exige pasar por los recursos de la imaginación y la ilusión" (2001, p.52). La apuesta de Maquiavelo por ir a la historia o a la experiencia

\footnotetext{
${ }^{13}$ Según Alberti, en su tratado pictórico Dela pittura, el pintor "debe proponerse como objetivo la ilusión en la representación de los cuerpos y la impresión de realidad viva. Al artista debe exigírsele como al orador, una formación amplia en las artes liberales para que esté en condiciones de utilizar los medios técnicos, como la construcción de la perspectiva, indispensables para una representación ilucionista. (...) La ilusión contribuye a la sugestividad de la representación; hace aparecer a las figuras y a la acción representada como reales, con lo cual el efecto buscado sobre la psique del espectador queda garantizado". (Pochat, 2008, pp. 217-226).
} 
requiere del uso de la imaginación para inferir y transmitir sus pautas de acción política que implican un notable esfuerzo descriptivo de los hechos del pasado para recuperarlos y ubicarlos en la argumentación.

El uso de la imaginación en Maquiavelo se observa en su argumentación, primero, en la aproximación a la experiencia, pero también en la previsión imaginaria de las acciones futuras. Maquiavelo recurre a la imaginación como una facultad necesaria para trasladarse a la historia, recuperar la experiencia, pero también porque permite "al espíritu que se aplica, de manera imaginaria, a considerar las situaciones posibles y las respuestas a dar en función de las diferentes circunstancias" (Gaillé, 2001, p. 102). Gaillé sostiene esta tesis a partir del ejemplo de Filopemen, príncipe de los Aqueos que aparece en El Príncipe capítulo XIV. En el ejemplo, Maquiavelo elogia el hábito que tenía Filopemen de leer a los autores antiguos pero también de "llevar a cabo ficticias campañas guerreras ${ }^{14 "}$. Filopemen, explica Maquiavelo, tenía el hábito de pasear con sus amigos por el campo y les sugería que se imaginaran posibles escenarios de batalla, logrando así ser un maestro de la previsión lo que le permitía actuar con seguridad, pues cuando tuviera que intervenir en la realidad, ya tendría las pautas de acción necesarias para actuar en posibles escenarios que se le presentasen.

El uso de la imaginación en Maquiavelo, según Marie Gaillé, se observa en dos aspectos, primero, en la aproximación a la experiencia (antigua o próxima en el tiempo) y segundo, en la previsión imaginaria de las acciones futuras. La primera es propia del método que utiliza Maquiavelo para ir a la experiencia, mientras que la segunda corresponde más a una sugerencia que hace Maquiavelo al príncipe para que ninguna eventualidad le sorprenda, ya que con el ejercicio de la capacidad imaginativa ha de estar preparado para actuar ante cualquier escenario.

\section{La imaginación en Gaille y Ricœur}

Hasta el momento hemos sostenido que el contexto humanista de la época de Maquiavelo influyó en la orientación de su conocimiento hacia la práctica. Posteriormente repasamos la visión de la historia como magistra vitae expuesta por Samamé para ver cómo la historia cobraba sentido en el discurso maquiaveliano

\footnotetext{
${ }^{14}$ Según Maquiavelo, cuando Filopemen estaba en paseando en el campo con sus amigos, frecuentemente se detenía y discutía con ellos: "Si los enemigos estuvieran en esa colina y nosotros nos encontramos aquí con nuestro ejército, iquién de los dos tendría la ventaja? ¿Cómo sería posible, conservando el orden, ir al encuentro de ellos? Si quisiéramos retirarnos, ¿cómo deberíamos hacerlo?" Y, avanzando, les exponía todos los casos que podían presentársele a un ejército, escuchaba la opinión de sus amigos, expresaba la suya, la sostenía con razones, $\tan$ bien que, gracias a esas continuas cogitaciones, cuando guiaba a sus ejércitos, nunca podía suceder ningún accidente que no tuviera remedio". Maquiavelo, (citado por Gaillé, 2011).
} 
en la medida en que ésta era útil para la praxis política. Luego pasamos revista a las interpretaciones de Cassirer y Horkheimer quienes sostienen que Maquiavelo, a partir de una concepción particular de la naturaleza humana basada en las regularidades, erigió las bases de una ciencia de la política. El valor predictivo de esta ciencia permitiría el desarrollo seguro de la acción política. Pese a las posturas anteriores, con el aporte de Marie Gaillé reconocemos que existe una alternativa distinta a la propuesta de Cassirer, Horkheimer y Samamé ${ }^{15}$, para postular la transmisión de un saber orientado a la acción desde la obra de Maquiavelo.

Como vimos anteriormente, Gaillé reconoce el papel de la imaginación en Maquiavelo para aproximarse a la historia, reafirmar el presente y hacer un movimiento hacia adelante para contemplar los posibles escenarios de acción. En este sentido Gaillé continúa con la corriente de pensamiento que concibe que El Príncipe es una obra que procura proveer pautas de orientación práctica ${ }^{16}$; sin embargo, introduce a la imaginación en la discusión sobre la forma como la obra maquiaveliana produce fórmulas orientadas a la acción. Gaillé sugiere, aunque no profundiza, la relevancia que tiene la imaginación para transmitir las recomendaciones políticas orientadas a la acción que se encuentran en toda la obra maquiaveliana, particularmente en El Príncipe. La mayor evidencia de que Gaillé no desarrolla con mucha extensión sus comentarios sobre la imaginación en Maquiavelo, radica en la ausencia de una definición o caracterización de la imaginación. Otro aspecto que deja abierto Gaillé es la relación que establece la autora entre la imaginación en Maquiavelo y la teoría pictórica de la época renacentista. En este último punto Gaillé solo hace provocativas relaciones entre dos temas relacionados, pero deja abierta la posibilidad a una investigación futura que precise dicha relación.

No obstante, con estos comentarios que deja abiertos Gaillé sobre la imaginación en Maquiavelo, es posible complementar el rol que cumple la imaginación como función del intelecto que le permite al pensador florentino recuperar la experiencia pasada y la cercana a su vida para reconstruirla mediante la facultad imaginativa. En Gaillé vemos expresada claramente la función de la imaginación para dar cuenta de la experiencia a través de su capacidad descriptiva, porque es la imaginación la que permite a Maquiavelo dar una impresión de realidad más contundente que la realidad misma; esta intención argumentativa se puede hallar en la propuesta maquiaveliana de ejemplos de hombres virtuosos dignos de ser emulados. Maquiavelo no solo recurre a sugerir los ejemplos de estadistas de "carne y hueso", como Alejandro Magno o el papa Alejandro VI, sino que también propone figuras mitológicas como Aquiles, Quirón o Moisés para reforzar el concepto de imitación de los hombres virtuosos de la antigüedad.

\footnotetext{
${ }^{15}$ Es preciso reconocer que Luciana Samamé observa el uso libre que hace Maquiavelo de la historia, pero también basa su aproximación al concepto de historia como magistra vitae en los supuestos de las regularidades de la vida humana como afirman Horkheimer y Cassirer.

${ }^{16}$ Aunque no conocimiento como sí lo creían Cassirer y Horkheimer.
} 
Sin embargo, este proceso descriptivo, según Paul Ricœur es un primer paso, ya que la imaginación permite la comparación de las descripciones, dando paso a la interpretación de los hechos comprometidos según la noción de imaginación trabajada por Paul Ricœur.

Para Ricœur, la interpretación y la imaginación están involucradas de forma simultánea en la experiencia imaginativa. La imaginación permite describir las experiencias antiguas y contemporáneas e interpretarlas de manera que produzcan nuevas maneras de acercarse a la acción presente. Esto sucede porque, según Ricœur, es solo a través de la suspensión del presente que a la imaginación le es posible la interpretación y la redescripción de los hechos pasados. La imaginación posibilita llevar a cabo abstracciones y relaciones entre los acontecimientos del pasado para hacer una extracción de sus significados, los cuales permitan ampliar el sentido mediante el cual se actúa en la realidad inmediata.

Por todo lo anterior, la noción de imaginación en Maquiavelo tratada por Gaillé comparte algunas de sus pretensiones interpretativas con la noción de imaginación elaborada por Ricœur. Sin embargo, es la noción de imaginación en Ricœur, la que nos permitirá ampliar los límites de la función imaginativa dentro de la argumentación maquiaveliana. En síntesis, según Ricœur, la imaginación es una facultad que media entre las percepciones del mundo y los conceptos del entendimiento, ella entrega las percepciones en forma de conceptos al entendimiento que los interpreta y le imprime una fuerza heurística a través del discurso. La imaginación posibilita "transportarse" al momento que se describe y al mismo tiempo permite la interpretación de lo que se describe, para solucionar necesidades impuestas por la acción.

Por lo tanto, tomando la imaginación como el medio que posibilita la ampliación de los horizontes prácticos en Ricœur, se logra introducir nuestra propuesta de investigación, pues más allá de la imaginación en sus capacidades interpretativas, descriptivas y de previsión ante las acciones futuras, la imaginación es también un prerrequisito para la elaboración y comprensión de metáforas, ya que, si por la imaginación se pueden comparar dos cosas que pertenecen a categorías distintas, el mundo y los conceptos, en el caso de la metáfora, esta comparación se realiza por medio de pensamientos, pues se hace un paralelo entre situaciones distintas. Por lo anterior, debemos explicar los alcances del concepto de la imaginación y cómo media entre la creación y la interpretación de la metáfora, para identificar cómo las metáforas maquiavelianas permiten la transmisión y comprensión en una forma simple de sus consejos al príncipe para orientar la acción política. 


\section{La metáfora en Paul Ricœur}

Por lo tanto, si instruir a sus lectores sobre la acción política es una particular intención de El Príncipe, (siguiendo las interpretaciones de Samamé, Cassirer y Horkheimer por las cuales ya hemos transitado en esta investigación), debemos reconocer que el texto maquiaveliano busca conectar su estructura narrativa con el mundo, con la intención de descomplejizarlo, recurriendo a la imaginación, la cual le permite organizar las enseñanzas de hechos históricos con el fin de intervenir en la realidad. Es por eso que los consejos prácticos hechos por Maquiavelo en su obra hacen uso de ejemplos de la experiencia antigua o contemporánea al autor, los cuales son organizados mediante la imaginación. Pues ésta le permite reescribir las acciones humanas, retomando la estructura narrativa de la historia para proyectar sus fórmulas de acción con la articulación, abreviación y simpleza que facilitan que sus tesis principales lleguen al lector de una forma clara en El Príncipe.

En este sentido Ricœur afirma que "la primera manera según la cual el hombre intenta comprender y dominar lo heterogéneo del campo práctico es la de procurarse una representación ficticia de él" (Ricœur, 1991, p. 205). Aquí es que los comentarios de Gaillé sobre la imaginación en Maquiavelo cobran sentido, pues es a través de la imaginación que los seres humanos se acercan a los problemas prácticos. Las "representaciones ficticias" que Maquiavelo hace de su experiencia mediante la imaginación, le permiten concebir un marco para la orientación de la acción política. Esta concepción enfatiza el sentido útil de las enseñanzas de la historia que sólo cobran sentido en la medida en que es útil para nuestra vida diaria.

El objetivo de esta indagación no es encontrar solamente el papel de la imaginación en la argumentación maquiaveliana. Nos interesa la imaginación porque es un requisito de las metáforas que posibilitan ampliar nuestra compresión sobre las fórmulas de acción política expuestas por Maquiavelo en su obra. Con la teoría de Ricœur podremos identificar sí las metáforas proporcionan la clave para que la complejidad de los problemas políticos sean presentados de manera sintética y de fácil asimilación para el lector, mediante la interacción de sus significados con conceptos que no pertenecen al mundo político.

Para resolver la incógnita anterior es preciso explicar cómo mediante la imaginación se logra acercar dos objetos o conceptos que están alejados, no por una relación de semejanza obvia, (la cual, por ejemplo, permitiría relacionar una pera con una manzana), sino mediante una semejanza inusitada a partir de la experiencia. En forma similar a como cuando se lee que el hombre es un lobo, de pronto se interpreta al hombre con características de lobo. A decir verdad, el concepto de hombre nunca cambió, lo que cambió fue la interpretación que 
se elabora de dicho concepto, esta experiencia súbita, al utilizar la imaginación, suprime la distancia de significados entre campos extraños y permite comparaciones ilógicas "organizadas" entre objetos. Esta mediación de la imaginación es la que permite organizar, suprimir y enfatizar ciertos significados que admiten la asimilación necesaria entre situaciones o conceptos, los cuales son fundamentales para abordar la forma en cómo la metáfora describe un concepto abstracto y facilita su comprensión.

Según Ricœur cuando cita a Kant, la imaginación proporciona un puente entre la percepción y el entendimiento, esto lo hace porque ella permite construir categorías para la percepción de los objetos y llevar a cabo la asignación de sus conceptos. Aquí la percepción provee insumos a la imaginación para que sintetice y combine lo diverso de la sensibilidad, dando reglas para la categorización de los objetos en conceptos que sean comprensibles para el entendimiento. Esta capacidad de síntesis a priori de la imaginación, (la que Kant denomina, imaginación productiva), hace posible conocer los fenómenos presentes en el mundo, permitiendo su reproducción según leyes, las cuales no se derivan de la experiencia puesto que ellas son un requisito para la experiencia. Sin dicha capacidad de la imaginación no se fundirían en una experiencia los conceptos y objetos (Kant, 1989).

A través de la imaginación se "ponen las condiciones mediante las cuales se forman las imágenes de los objetos" (Betancur, 2006, p. 145). Así, la imaginación está subordinada al entendimiento porque "si definimos el entendimiento en general como la facultad de las reglas, entonces el juicio consiste en la capacidad de subsumir bajo reglas generales (...) es decir, de distinguir si algo cae o no bajo una regla dada" (Kant, 1989, p. 133). Es así como se posibilita la creación de conceptos generales, bajo los cuales los objetos se rigen ante el entendimiento. Pero los conceptos solo se pueden formar sobre la base de ciertos presupuestos que denoten la regularidad en cualquier tipo de juicio, y es a través de esta capacidad de crear juicios a priori, que se asigna a los objetos como pertenecientes a una categoría, o a una clase. En este sentido, lo que hace posible la aplicación de la categoría a las experiencias, según Kant, es el esquematismo, el cual produce modelos generales de los insumos propuestos por la percepción, dando una estructura por medio de la cual interactúan las categorías conjuntamente con las intuiciones sensibles (Kant, 1989).

Por lo tanto, el esquematismo es el que acerca los objetos de la percepción y de los conceptos del entendimiento. El esquematismo se da por un proceso, mitad pensamiento y mitad visión, porque el que está teniendo la experiencia, también está pensando en el objeto sobre el cual tiene la experiencia. En este sentido, la imaginación proporciona esquemas, ella es, por un lado, un "ver", porque nos permite ver los objetos que son asignados por el significado de las palabras y un pensar, porque es mediante el pensamiento que podemos modificar la forma 
en cómo interpretamos un concepto. Así, cuando son acercadas las cualidades humanas con algunas cualidades del reino animal, tenemos la experiencia de ver a un animal como hombre, pero el pensamiento hace posible darle un sentido a esta experiencia; darle una utilidad, que cambia según el contexto.

La posibilidad de crear imágenes renovadas, de significaciones nacientes, creadas a partir del acercamiento de categorías o conceptos que estaban alejados y mediante la violación de las reglas semánticas y sintácticas, conjuntamente, con el proceso imaginativo lo que hace posible crear un nuevo sentido. Esta es la base angular que permite indefinidamente la interpretación. En este sentido, que lo que se interpreta de otra manera se ve de otra manera (Wittgenstein, 1988). Poder ver una cosa a través de otra es un tipo particular de experiencia que se ubica entre el ver y el interpretar, ya que obliga al lector a que asimile un nuevo sentido, lo cual le permite ver un objeto que no cambia, a través de otro (Betancur, 2006).

El espectador siente la necesidad de emplear un esquema que pueda expresar la nueva experiencia visual, cuando intenta interpretar un enunciado incongruente, y aplicarle un concepto renovado a la nueva imagen (Betancur, 2006). De esta forma, Ricœur especifica que cuando se lee o se usa el lenguaje somos presentados por una corriente de imágenes, que vienen circunscritas al significado de las palabras que estamos usando; esto también sucede cuando se presenta una impertinencia lógica en el uso del lenguaje, pero esta vez vemos imágenes que no vienen usualmente asociadas con su significado particular. Entonces, el lector es estimulado a interpretar la experiencia de ver un objeto de modo inusual. Aquí La imaginación no cumple solo una función descriptiva, sino también, una función reflexiva, pues no se trata de determinar o dar un informe objetivo de lo que se ve, sino que la imaginación "es una experiencia que incorpora una descripción" (Betancur, 2006, p. 192).

En medio del proceso imaginativo, la interpretación juega un papel importante en el hecho de tener la experiencia de ver una cosa en términos de otra, pues los conceptos pertenecientes a distintas clases aparecen súbitamente más cercanos. Es en el momento de asemejar un hombre con un lobo que el lenguaje no parece tener ninguna referencia con la realidad, en donde se crea una suspensión que posibilita la aparición de una referencia de segundo orden. Es decir, esta frase como un todo quiere decir algo más de lo está describiendo como real, así el lenguaje imaginativo, ejerce una suspensión sobre lo que estos conceptos usualmente referencian para crear una nueva referencia indirecta a la realidad, la cual es hecha a partir del choque de los significados literales de estos conceptos. En este sentido, la imaginación no solo muestra de una forma simplificada una cosa bajo las propiedades de otra, como tampoco, solamente, se dedica a entender el significado de las imágenes que son controladas por el proceso cognitivo. La imaginación entonces, contribuye concretamente a la suspensión de la referencia usual entre conceptos y proporciona la proyección de posibilidades de segundo orden mediante las cuales es posible entender el mundo (Ricœur, 1978). 
Por lo tanto, entendida la imaginación como el procedimiento de organizar los significados de los conceptos para poder tener la experiencia de ver nuevas asociaciones, a través de la suspensión de la referencia ordinaria al mundo, es que, advierte Ricœur, se puede concluir que la función de la imaginación posibilita "un libre juego con las posibilidades, en un estado de no compromiso con respecto al mundo de la percepción o de la acción. En este estado de no compromiso, ensayamos nuevas ideas, valores nuevos, nuevas maneras de estar en el mundo" (Ricœur, 1991, p. 203). Como vimos en Gaillé, la descripción sobre la experiencia está filtrada por los recursos de la imaginación, utilizada para darle más fuerza a las ideas y permitir la reconstrucción de la experiencia, pretendiendo dar una descripción de la realidad cuando se está brindando una impresión de la misma.

Explicado el papel de la imaginación como el procedimiento que nos permite acercar dos conceptos que están, en principio, alejados uno de otro y que tiene, además, como función entender el significado de las imágenes que son a la vez, producto y controladas por la experiencia de leer o pensar, y por último es en la imaginación, que mediante la supresión de la referencia del discurso ordinario se puede abrir el campo de las referencias indirectas a la realidad que incrementen la capacidad para la acción. La teoría de la metáfora ofrece la posibilidad de vincular la imaginación con el uso del lenguaje, en donde cumplen una función conjunta en la redescripción de la referencia a la realidad. En este sentido, Ricœur define la metáfora como "un uso desviado de los predicados en el marco de la oración entera (...) ella (la metáfora) regula el empleo de los predicados extraños, y de esta falta de pertinencia predicativa produce un conflicto entre campos semánticos. Para responder al desafío nacido del conflicto semántico, se hace uso de la imaginación ${ }^{17}$, la cual produce una nueva pertinencia predicativa que es la metáfora (Ricœur, 1991, p.201).

Cuando, en una oración se utilizan predicados o ideas de una manera distinta a como son utilizadas normalmente por una comunidad de hablantes, se produce un choque de sus significados literales, provocando el surgimiento de un nuevo significado de las ruinas de la interpretación literal, lo que invita al lector a hacer uso de la imaginación para acercar dos ideas extrañas. Así la metáfora regula la agrupación de predicados extraños por medio de la reestructuración de sus campos semánticos, dado que obstruye las fronteras semánticas ya establecidas, para hacer aparecer semejanzas, que la significación usual de las ideas no consentía, logrando así una asimilación en sus significados. "Tanto metaforizar como imaginar supone la reestructuración de los campos semánticos." (Ricœur, 1991, p. 202). Este tropo consigue, entonces, la resolución del conflicto semántico permitiendo su reintegro a la congruencia.

${ }^{17}$ Cursivas son nuestras. 
Por ejemplo, si utilizamos esta metáfora: "el hombre es un lobo para el hombre" podemos entender que literalmente esta oración no tiene sentido, ya que se está desviando el uso normal de estos predicados; así el concepto de hombre no corresponde en su representación al concepto de lobo, en el sentido en que es aplicado usualmente por una comunidad de hablantes. Por ende, estos están obligados (al igual que sus lectores) a buscar las posibles maneras en cómo el sujeto es modificado (a través de la imaginación) por el predicado, buscando las significaciones literales de hombre y de lobo que puedan ser compatibles entre sí. En este sentido, la metáfora da forma al discurso, genera imágenes para los nuevos significados. Esto porque el resultado de la metáfora no es una copia, ni de hombre, ni de lobo, sino una organización de sus significados que los inserta de una forma creativa en la realidad. Es a partir del ícono descriptivo que podemos ver nuevas características de lo que la palabra "hombre" usualmente significa y utilizarlo en la compresión nuestra del entorno.

Esta operación, que organiza los significados es hecha mediante un ejercicio de analogía entre los predicados recientemente creada por el esquematismo hecho en la imaginación, pues es tarea de este, proveer una nueva imagen a la significación emergente. Esta imagen es una organización, ella suprime o enfatiza ciertos semas de un sujeto y ciertos semas de un predicado, para nivelar sus significados, tolerando las semejanzas entre uno y otro, lo que resulta en una congruencia metafórica. Procediendo con nuestro ejemplo, el "hombre" posee por su semejanza de ser vivo en un ambiente que le demanda unas respuestas efectivas para sobrevivir una analogía con las características que sean aplicables del lobo, las cuales pueden ser, pensar siempre en beneficio propio, y en detrimento de sus coetáneos. Esta forma en cómo el concepto de "hombre" hizo un esquema del concepto de "lobo", es la que difumina sus fronteras lógicas para permitir asignarle una imagen a esta significación emergente, la cual se ha convertido en su icono. En este sentido esta imagen se refiere a estos conceptos de manera secundaria, a partir sus significados primarios, es decir, el hombre ahora tiene características de lobo, esta nueva imagen la cual es asignada en un contexto específico a la imagen que por el significado de hombre tenemos en nuestra comprensión, siendo esta nueva imagen la que nos da una regla o una dirección para comprender la re-descripción de "hombre". Esta dirección es el icono que la metáfora crea (Ricœur, 2003).

Como ya hemos visto, la metáfora describe las condiciones bajo las cuales una situación o un objeto se pueden comprender a través de otro y establece conexiones entre una frase leída y otras experiencias vividas. Estableciendo analogías, entre situaciones, hechos o sentimientos. Su función es dejar propuesta la posibilidad de considerar un campo teórico a través de otro, de sistematizar una red conceptual a través de otra, a través de la imagen icónica. En el caso de metáfora se presenta una dimensión verbal de esta imagen, al igual que esta imagen es asignada a una significación naciente, este es el lugar de la reestructuración 
semántica. El icono es la creación de una nueva pertinencia semántica, nace de las ruinas de las áreas semánticas en contradicción. Es mediante el hecho de no requerir una imagen como tal, sino de describirla, que se aportan consecuencias ventajosas para la metáfora, pues puede llevar a cabo comparaciones insólitas (Betancur, 2006).

La metáfora, entonces, tiene una aplicación que apunta hacia afuera de la esfera del lenguaje porque relaciona el lenguaje con las cosas. El ícono designa el 'no lugar' en relación con toda la realidad y se dirige indirectamente ella, esta función de la metáfora ejerce en el lenguaje, a través de la imaginación, el poder de la ficción para re describir la realidad. Esta cualidad ficticia del lenguaje permite, combinada con la cualidad descriptiva del lenguaje con respecto a la realidad, la posibilidad de imprimir cursos de acción desde la ficción como un método para enriquecer la práctica. Lo esencial desde este punto de vista, es que no se toma posesión de la certeza de poder sino a través de las variaciones imaginativas que permiten aplicar este poder en la realidad (Ricœur, 1991). La metáfora se basa en la posibilidad imaginativa de crear desde la ficción, formas de relacionarse con la realidad, que es soportada mediante el lenguaje en la expansión de los significados de las palabras o la creación de expresiones del lenguaje, que derivan en una ampliación del significado de la realidad; siendo la metáfora un elemento del lenguaje el cual es fundamental para entender el mundo que nos rodea. En este sentido, la metáfora se dirige hacia las realidades desde la ficción, realidades que están ausentes de la realidad natural (Ricœur, 1978); es gracias a la suspensión de esta realidad que se despliega su capacidad de abrir nuevas dimensiones de realidad. Es la imaginación la que proporciona un medio en donde pueden compararse y medirse motivos tan heterogéneos como los deseos y las exigencias éticas, las reglas profesionales y las reglas sociales, generando conexiones nuevas entre los distintos campos para que faciliten la acción (Ricœur, 1991).

La teoría sobre la metáfora en Ricœur nos aporta nuevas posibilidades de interpretación a las metáforas en El Príncipe, estas son utilizadas como un medio para descomplejizar la argumentación con el fin de transmitir un conocimiento sobre una forma de actuar en política. Mediante el uso de atribuciones innovadoras (metáforas), el florentino procede a re describir las posibilidades con las que presenta sus ejemplos históricos para hacerlos interpretables a la luz de una tesis fuerte que está sugiriendo. En este sentido, al interpretar las metáforas de El Príncipe, el autor permite al lector incorporar sus principales innovaciones de sentido a su experiencia de vida; el significado que cada metáfora transmite, incrementa el cúmulo de conocimiento del lector, lo cual puede ser usado como una herramienta dirigida a la acción, son estos nuevos significados los que facilitan la comprensión de fórmulas para la acción que descomplejizan los conceptos abstractos que desean ser transmitidos. 


\section{Metáforas en el príncipe}

Acabamos de realizar una breve síntesis sobre los planteamientos de Ricœur acerca de la teoría de la metáfora, en la que observamos cómo la imaginación cumple un rol fundamental para que la metáfora pueda ser creada por el autor y comprendida por el lector. Reconocimos que es gracias a la imaginación que se puede superar la incongruencia de la interpretación literal de la metáfora y, acto seguido, evocar una nueva significación congruente sobre el enunciado metafórico, lo que posibilita la comprensión de nuevos conceptos y la reorientación de la acción en la realidad. El siguiente paso es ir al texto directamente con el objeto de realizar el análisis de tres metáforas presentes en El Príncipe a la luz de la teoría expuesta de Paul Ricœur y poder corroborar la función del proceso metafórico en la obra del pensador florentino.

Las metáforas que fueron escogidas del texto para ser analizadas son: la metáfora pictórica expuesta en la dedicatoria de El Príncipe; la metáfora del arco y la flecha; y la metáfora de la zorra y el león. Cada una de ellas nos habla sobre un problema concreto en la argumentación maquiaveliana. La metáfora pictórica se ubica en un plano epistemológico, pretendiendo validar el punto de vista del escritor para dar cuenta de sus observaciones; la metáfora del arco y la flecha alude al papel de la historia como magistra vitae y al rol de la imitación en política; y, por último, la metáfora de la zorra y el león nos habla de aquellas facultades que debe tomar de la naturaleza el príncipe para gobernar eficazmente. Cada una de las metáforas gira en torno a un eje temático clave en El Príncipe, por lo que en ellas podremos encontrar la función argumentativa que cumplen en el contexto mismo de argumentación que las rodea.

Las metáforas que tuvimos en cuenta fueron aquellas denominadas por Ricœur como metáforas vivas, es decir, aquellas que indican una nueva comprensión sobre un problema u objeto, y que no se agotan en la mera sustitución del concepto figurado por el concepto literal (metáforas muertas ${ }^{18}$ ). A partir de un análisis de las características de estas tres metáforas, podemos comprobar o rechazar la tesis con la que empieza esta investigación, a saber, que la metáfora juega un papel importante en la argumentación en El Príncipe porque ésta le permite a su autor sugerir herramientas que permiten referirse a objetos que están fuera del mundo

\footnotetext{
${ }^{18}$ Una metáfora muerta es aquella cuyo concepto de uso figurado puede ser sustituido por uno equivalente de sentido literal porque el cambio en la significación ente uno y otro es nulo. Por ejemplo, en El Príncipe encontramos un metáfora muerta cuando Maquiavelo (1998) habla de los principados hereditarios y cómo éstos le resultan más fáciles de gobernar al príncipe. Afirma Maquiavelo que cuando hay cambios drásticos en el gobierno, estos cambios "dejan siempre una piedra angular para producir otros" (p. 24). Al cambiar en este enunciado metafórico el término "piedra angular" por bases, pilares o cimientos, la significación de la expresión prácticamente no varía, por consiguiente es una metáfora muerta. Las metáforas que trabajamos en esta investigación son todas metáforas vivas.
} 
político y relacionarlos con aspectos propios del mundo político, lo que permitirá la redescripción de conceptos abstractos para que sean presentados de manera sintética y de fácil aplicación en la ordenación de cursos de acción política.

\subsection{La metáfora pictórica}

La primera metáfora que abordaremos es la que Gaillé (2011) denomina la metáfora pictórica. Esta metáfora está al principio de El Príncipe en la dedicatoria de la obra a Lorenzo de Médicis. A primera vista, pareciera que la utilización de esta metáfora consiste simplemente en una estrategia del escritor por embellecer el discurso. Sin embargo, aclara Maquiavelo sobre El Príncipe cuya redacción no ha "adornado ni hinchado con amplios períodos o con palabras ampulosas y solemnes, o con cualquier otro rebuscamiento u ornamento superfluo, recursos con los que muchos suelen describir y adornar sus obras. Yo por mi parte, he querido o que nada la distinga o que tan sólo la haga grata la singularidad de la materia y la importancia del tema" (1998, p.34).

Maquiavelo afirma que él no es partidario de aquellas estrategias argumentativas que, en la tradición humanista de su época, sí eran comunes, pues la mayoría de profesores de retórica buscaban alcanzar el refinamiento del discurso al punto de anhelar alcanzar el estilo perfecto (Skinner, 1985). Apartándose de esta corriente, Maquiavelo afirma que basta la "singularidad" y la "importancia del tema" para decir algo que valga la pena de ser escuchado por un príncipe como Lorenzo.

Maquiavelo busca pues legitimarse ante su interlocutor. Siendo un ciudadano común, un ex funcionario público caído en desgracia que pretende ser devuelto al trabajo público, debe hacerle entender al príncipe que su escrito vale la pena por su contenido y no porque sea una prueba del arribismo de un particular que pretende enseñarle a un gobernante cómo ejercer sus funciones. Es aquí cuando la metáfora pictórica entra en escena. Maquiavelo explica el hecho de que sea él, un hombre "ínfimo", el que se atreva a sugerir pautas de acción para un "eminente" gobernante, "porque así como quienes dibujan un paisaje se sitúan en el punto más bajo de la llanura para estudiar la naturaleza de las montañas y de los lugares elevados, y para estudiar la de las planicies ascienden al punto más elevado de los montes, de la misma forma, para conocer bien la naturaleza de los pueblos, es necesario ser príncipe y para conocer bien la de los príncipes es necesario formar parte del pueblo" (1998,p.34).

En esta metáfora podemos observar que la perspectiva del príncipe y la del pueblo (o el observador que está entre el pueblo) son puestos en tensión por su inusitada comparación y asimilación. Esto sucede porque el príncipe y el pueblo pertenecen a esferas distintas de la jerarquía social que chocan entre sí por tener perspectivas distintas sobre los fenómenos políticos. Esta metáfora lo que propone 
es la posibilidad de reunir estas dos esferas, alimentarlas mutuamente, aunque en su uso común estén alejadas, promoviendo una nivelación en sus significaciones para permitir la semejanza.

Como las perspectivas que cada uno tiene como propias de su condición social son incompatibles, la interpretación literal indica que el gobernante está por encima de toda la organización social, alejado de la "realidad" del pueblo, siempre aislado de las interacciones propias del grueso de la población y por lo tanto a una distancia considerable que le impide conocer a plenitud la naturaleza del pueblo que gobierna. Es como si el gobernante no pudiera descender de su eminente condición a una más cercana a su pueblo, como si permaneciera estático, encerrado en su palacio de gobierno. A su vez, la imposibilidad del pueblo para conocer la naturaleza de los príncipes radica en que su condición baja no está en contacto directo con los despachos oficiales, no tiene las capacidades para comprender los asuntos de Estado y su condición es más pasiva que activa, como para proponer un punto de vista acertado sobre la dirección de las decisiones gubernamentales.

Pese a lo anterior, lo que permite superar esta incongruencia de las interpretaciones literales es que a través de la imaginación como vimos en Ricœur, es posible reestructurar los campos semánticos de un objeto o idea para que se haga compatible con otra. En este caso particular, la metáfora pictórica nos permite comprender el punto de vista del gobernante y el del pueblo como el uso de la perspectiva que hace un artista al contemplar un paisaje. La imaginación induce, por un lado, a los lectores de esta metáfora a concebir el punto de vista del gobernante como el punto de vista que tiene un artista que contempla con claridad desde lo alto de una montaña la extensión de sus dominios y las "planicies" en la parte baja. Por otro lado, el punto de vista del pueblo se emparenta a través de la imaginación con el punto de vista que tiene un artista que divisa, desde "el punto más bajo de la llanura", la grandeza de las montañas y sus partes elevadas.

El punto de congruencia de este enunciado metafórico radica en que tanto el gobernante y el pueblo, como el artista que se ubica en la parte alta y llana de un paisaje, tienen una perspectiva válida sobre lo que contemplan. Cuando se acepta a través de la imaginación que tanto el gobernante, el pueblo y el artista tienen un punto de vista único, desde el cual pueden decir algo sobre lo que observan que otro sujeto en otra posición no podría ver, es cuando se supera la contradicción lógica que la interpretación literal ofrecía. Es aquí cuando la metáfora cobra sentido y adquiere congruencia.

En el caso del gobernante, la "materia" a la que debe observar para luego conducir con prudencia es su pueblo; el cual contempla desde una posición prominente que le permite ver casi la totalidad del "horizonte político". Sin embargo, el gobernante no se ve a sí mismo. Desde la perspectiva del pueblo 
es posible observar el modo de conducirse de los gobernantes y así identificar sus éxitos y fracasos. Por el lado del artista, se sugiere que la perspectiva nítida y completa del paisaje que debe plasmar en el lienzo se debe a que tiene en cuenta ambas miradas (la de la parte alta o la de la planicie) dependiendo de la cuestión que contempla. Esta característica integral del artista, que es capaz de adoptar los dos puntos de vista (el alto y el bajo) es la que se sugiere debe ser tenida en cuenta en el campo político.

Con esta metáfora Maquiavelo exige ser validado como interlocutor por lo que sugiere que la política exige mínimo los dos puntos de vista mencionados, el del príncipe (al que le habla) y el del pueblo (donde se encuentra o por el que habla). Ya que Maquiavelo se dirige a un gobernante, su intención argumentativa es indicarle al lector que acepte su punto de vista pues la comprensión de los asuntos de Estado quedarían incompletos sin la perspectiva del pueblo. Es precisamente a partir de esta evocación, que parte de la semejanza, que la imaginación produce en los lectores una nueva pertinencia semántica sobre el concepto del punto de vista del gobernante y el del pueblo, en la medida en que el punto de vista de gobernante y el de pueblo es ampliado por el posible doble punto de vista del artista.

La innovación que introduce la metáfora pictórica está en que la perspectiva múltiple que debe procurar un artista, dependiendo del objeto que pinta, es aplicada al terreno político. En este sentido, el punto de vista en política no debe ser único, sino que debe ser múltiple, permitiendo la perspectiva desde diferentes actores para dar cuenta de un fenómeno político. En este sentido, con la metáfora pictórica se sugiere que para el ejercicio del gobierno eficaz es necesario para el príncipe el punto de vista, que tiene por su propia condición claro está, pero también el de otros actores, por lo menos el del pueblo.

Para Gaillé (2011) esta metáfora sugiere que para Maquiavelo cualquier intención de formular un juicio político nunca será, como interpretaron Cassirer y Horkheimer sobre la obra del pensador florentino, general y absoluto. Por algo no basta el punto de vista del gobernante. Por el contrario, la metáfora pictórica nos permite concebir que cualquier juicio en política siempre estará sujeto al punto de vista desde el cual se formule y que cualquier pretensión de verdad, así sea la "verdad oficial", siempre deberá aceptar que el saber en política es acumulativo y nunca definitivo. El saber en política siempre será una aproximación sujeta nuevas interpretaciones y no el resultado de una ley o afirmación definitiva como interpretaron Cassirer y Horkheimer sobre la obra del secretario florentino. Es por esto que la metáfora pictórica y su invitación a la perspectiva múltiple invita a adoptar una actitud epistemológica que aclare panorama para la intervención política. 


\subsection{La metáfora de la zorra y el león}

La metáfora de la zorra y el león se encuentra en el capítulo XVIII de El Príncipe. El capítulo comienza afirmando que la experiencia ha tumbado los presupuestos del humanismo sobre el modo que ha de seguir un príncipe para mantener la palabra dada. La experiencia, según Maquiavelo, indica que los "príncipes que han tenido pocos escrúpulos con sus promesas y han hecho un uso prudente de la astucia, han superado en sus conquistas a quienes se han fundado en la lealtad" (Maquiavelo, 1998, p .104). Pero en este punto, la argumentación de la obra se detiene para afirmar que hay dos formas de "combatir "en la arena política, mediante las leyes y la fuerza. La primera es propia de los hombres y la segunda de las bestias. Cuando se introduce la noción de fuerza como característica propia de las bestias, Maquiavelo recurre al lenguaje figurado para dar cuenta de sus fórmulas de acción. Por ejemplo, recurre al mito del centauro Quirón, quien por su condición de ser mitad bestia y mitad hombre, está en la capacidad de enseñar a los príncipes (como lo hizo con Aquiles) de usar la fuerza y la inteligencia cuando las circunstancias lo ameriten, comprendiendo que la "una no dura sin la otra" (Maquiavelo, 1998, p. 104).

La interpretación de esta metáfora, a través de la hermenéutica de Ricœur, nos lleva a buscar donde "chocan" los campos semánticos de príncipe y de bestia. La enunciación metafórica indica que "a veces el príncipe se ve obligado a comportarse como bestia". Esto en la medida de la necesidad y no por su deseo fútil, deseo claramente expresado a lo largo de la obra, sobre el uso efectivo de la fuerza por la necesidad de supervivencia del Estado. De entre los animales que existen, el príncipe debe extraer las características humanas que se le adjudican en el uso ordinario del lenguaje a la zorra y al león, puesto que son características propicias para el ejercicio del gobierno. El enunciado metafórico indica que: "el príncipe, debe actuar como león y como zorra, ya que el león no puede defenderse de las trampas y la zorra no se puede defender de los leones" (Maquiavelo, 1998, p. 104).

La metáfora como solución del conflicto semántico entre príncipe y bestia, toma del contexto argumentativo sus especificaciones direccionando la interpretación de la metáfora. El príncipe en tanto ser dotado de virtud política debe escoger las situaciones en donde es conveniente usar las distintas armas en su poder, cuando la necesidad lo indica debe proceder como león o como la zorra. Del león extraerá la fuerza y autonomía que le permitirá estar seguro. De la zorra, aprenderá a estar "doblemente seguro", ya que además de la gran fuerza del león, también tendrá astucia para evitar las trampas. Ésta nueva descripción de las cualidades necesarias para un príncipe se erigen como un compendio de cualidades humanas que se reconocen en el mundo animal, y sobrepasan la interpretación usual de los conceptos en juego. 
El proceso metafórico facilita, por un lado, al concepto 'príncipe' ampliar su espectro de significación y su campo de maniobra cuando las necesidades lo obliguen, pues no debe permanecer estático en un mundo esencialmente cambiante. Mediante la identificación de la astucia como una cualidad humana que suele adjudicarse a la zorra, y por otro lado, la comprensión del papel de la fuerza como una característica propia de las bestias, en este caso del león, amplía las posibilidades del príncipe para usar las herramientas a su disposición al gobernar. Esta metáfora hace alusión, en específico, a la fuerza como complemento de la aplicación de las leyes, y es entonces una ampliación de sentido de las posibilidades en como la fuerza puede ser utilizada, ya sea de forma astuta o de forma bruta. Lo que se pretende sintetizar a través de los conceptos de zorra y león, es el concepto de virtú política. Con la metáfora, entonces, de la zorra y el león, es posible comprender que la virtud política en Maquiavelo guarda las dos cualidades mencionadas anteriormente, el uso efectivo de la fuerza y la astucia o ingenio.

Maquiavelo se aleja del concepto de virtud cristiana, pues ésta no permitiría, por sus principios morales, llevar a cabo las acciones necesarias para conseguir la salvación de un principado. Dentro de la tradición cristiana, las virtudes de la humildad y la obediencia a conceptos trascendentales siempre fueron representadas con las ovejas o corderos, pero nunca como una zorra, como propone Maquiavelo. Para la virtud política, es de importancia cardinal acoplar el proceder ágil y artificioso propio de la zorra ya que esta condición le permite al príncipe develar conspiraciones, engañar con arte a los enemigos del Estado, mantener una apariencia benevolente frente a su pueblo, en suma, estar dispuesto a tomar las variaciones que la fortuna exija de él y por último, "a no apartarse del bien mientras pueda, pero también a saber obrar por la senda del mal cuando no quede otro recurso" (Maquiavelo, 1998, p. 105). Para saber cómo actuar, el príncipe requiere de la astucia de la zorra, y para asegurar su acción (además de defenderse) debe poseer la fuerza del león. La fuerza del león alude como hemos dicho a la primacía de la fuerza militar como sustento del poder político.

En la metáfora de la zorra y el león se percibe cómo Maquiavelo realiza un llamado a la acción, e indica el deber ser del príncipe según las exigencias de ciertas circunstancias particulares, fortaleciendo las prescripciones sobre la astucia y la fuerza para adecuarse a los desafíos del entorno y cultivar la virtud política. La metáfora permite comprender mejor esta pauta de acción que a su vez renueva la forma en que el gobernante interactúa con el mundo político, sus principales actores y problemáticas. La metáfora de la zorra y el león alude al tema de las características que deben distinguir a un príncipe, aquellos insumos sin los cuales no podrá virtud política para permanecer en el gobierno, ni mucho menos para alcanzar la gloria. 


\subsection{La metáfora del arco y la flecha}

La metáfora del arco y la flecha se encuentra en el capítulo VI de El Príncipe, en donde se habla específicamente de cómo un príncipe siempre debe buscar modelos de hombres ilustres en la historia, para imitar el calibre de sus proezas, buscando llegar tan alto como ellos han Ilegado. El tema general del capítulo trata sobre la forma en que se debe gobernar los principados nuevos adquiridos por el valor personal y las armas. En este capítulo se percibe el interés de Maquiavelo por fundamentar con claridad, lo que hemos llamado con Samamé, su concepción de la historia como magistra vitae. Lo anterior se evidencia en una metáfora que se encuentra al principio del capítulo y que sirve de antesala a la del arco y la flecha. Afirma Maquiavelo que los "hombres caminan siempre por caminos trillados ya por otros, y apenas hacen más que imitar a sus predecesores en las empresas que llevan a cabo" (1998, p. 48). Con esta expresión metafórica, Maquiavelo supone la regularidad que existe en las acciones de los hombres, como vimos que afirmaron varios de sus intérpretes como Samamé, Cassirer y Horkheimer. Pese a lo anterior, el pensador florentino hace una aclaración: los hombres que están a punto de actuar en política no pueden seguir al pie de la letra el camino que han trazado los antiguos hombres, ni tampoco alcanzan a aquellos hombres que se alzan como modelos de su conducta. Por eso, los hombres que quieran destacarse en sus acciones deben imitar tan solo "el modelo de algunos varones, especialmente aquellos que sobrepujaron a los demás, a fin de que, si no consiguen igualarlos, a lo menos ofrezcan sus acciones cierta semejanza con las de ellos" (Maquiavelo, 1998, p. 48). Tales ejemplos no son alcanzables por ser extraordinarios, pero sí son idóneos para establecer parámetros orientativos de la acción política.

Maquiavelo presupone entonces, la "historia monumental" que comentamos con Samamé, pues dada la regularidad de las acciones humanas, los hechos del pasado son útiles para orientar nuestras acciones. De la historia se puede aprender mucho para la acción política, pero especialmente de la historia monumental, porque al no poder repetir las hazañas de los hombres del pasado, tal cual como fueron realizadas, es preciso imitar sobre todo a los más grandes, para tener así un objetivo al cual seguir y, si no se les iguala, por lo menos se alcance "rozar" parte de su legado. En este contexto, "los hombres prudentes han de hacer como los arqueros experimentados que, cuando tienen que dar en un blanco muy lejano, y dado que conocen el alcance de su arma, apuntan por sobre él, no para llegar a tanta altura, sino para acertar donde se lo proponían con la ayuda de mira tan elevada" (Maquiavelo, 1998, p. 48).

El conflicto semántico se genera entre los significados literales de príncipe y de arquero, el cual genera un conflicto de predicados en el marco de la oración entera. En este punto, se produce la asimilación de los distintos semas de estas dos ideas que surgen de la metáfora. Son esas características semejantes las que 
permiten su "equiparación". Desde las significaciones literales de cada concepto, podemos inferir que el príncipe no tiene mucho que ver con un arquero, salvo la relación de superioridad que representa el príncipe sobre el arquero en tanto jefe del ejército de una nación. Sin embargo, cuando se recurre a la imaginación se produce una transferencia entre campos de la actividad humana distintos para traer del ámbito militar, y en especial del arte del arco y la flecha, algunas de sus propiedades al ámbito de la política. Es así como el príncipe, para imitar las acciones de sus predecesores, especialmente los que según Maquiavelo son verdaderamente grandes y de mayor condición, relacione con esta metáfora el objetivo al que ha de llegar el hombre de Estado (que desea alcanzar a Moisés, Aquiles o David) al objetivo al que debe llegar la flecha que el arquero lanza. Tanto el político como el arquero tienen un objetivo.

Para alcanzar tal objetivo, tanto el arquero como el político deben apuntar más alto para lograr si quiera una meta que se consideraría honorable. La flecha realiza una parábola después de ser lanzada por el arquero, que al ir bajando por el influjo de la gravedad terminará asestando en el blanco. Pero en un principio, el arquero apuntó más alto del objetivo que tenía en mira. Lo mismo ha de hacer el político, pues para alcanzar una posición honorable, es preciso que imite a los más grandes, no para alcanzarlos (como no alcanzo el arquero el punto elevado al que apuntaba) sino para que, reconociendo los límites de sus capacidades (el arco en el arquero) el político llegue a un objetivo acorde con su condición y fuerzas.

En este sentido esta metáfora, sugiere una pauta para la acción en la medida en que remite a la historia como maestra de vida, o mejor, como maestra en política. La metáfora indica, recurriendo a conceptos y objetos que no son propios del lenguaje político, que para alcanzar una posición notable es necesario apuntar alto y seguir los pasos de los héroes de la antigüedad. Al haber escogido los modelos más altos, no alcanzarlos igual implica haber alcanzado una posición importante.

Del uso desviado de los predicados príncipe y arquero que se da paso a la creación de un icono descriptivo, el cual regula y organiza los semas de cada uno que deben ser acentuados o suprimidos para que sea posible una asimilación en sus significados. Es por medio de este ícono que se responde al desafío del conflicto en los campos semánticos, es así como, esta ficción sale de sí misma y permite sugerir al príncipe más posibilidades para su implementación en la acción; se amplía el concepto de príncipe para que acoja algunas de las acepciones de un arquero. El príncipe recrea para sí de forma simbólica las acciones del arquero, pero extrayendo de tales acciones el sentido que toma en el contexto de la metáfora. Así es que esta metáfora puede ser comprendida y orientativa de la acción política. 


\section{Conclusiones}

Para resolver el problema planteado en esta investigación, primero afirmamos desde la aproximación de Luciana Samamé al concepto de historia en Maquiavelo, que la noción de historia como magistra vitae presente en la obra del pensador florentino implica la concepción de la historia como un saber orientado a sugerir pautas de orientación para la acción política. No obstante, para que la historia pueda ser útil en la orientación del presente, era imprescindible desarrollar los aportes de Max Horkheimer y Ernst Cassirer como autores que sugieren una perspectiva de interpretación sobre El Príncipe que vincula la conceptualización y la acción sobre la política. Para estos autores Maquiavelo propuso una "ciencia de la política" que se basaba en las regularidades históricas de la naturaleza humana, lo que posibilitaba la generación de enunciados generales y la predicción, facilitando la acción política desde bases conceptuales sólidas. Según Horkheimer y Cassirer en sus lecturas de Maquiavelo, este factor común son las pasiones y los deseos humanos. Posteriormente, recuperamos los comentarios de Mary Gaillé sobre la imaginación práctica en Maquiavelo y los ampliamos con el uso la de imaginación según Paul Ricœur. Con este puente establecido, procedimos a explicar el papel de la imaginación en su papel explicativo en la metáfora, para luego explicar cómo la metáfora posibilita la comprensión de las fórmulas orientadas a la acción política en El Príncipe. Por último, la teoría de Paul Ricœur sobre la metáfora nos posibilitó iniciar el abordaje del análisis de tres metáforas presentes en El Príncipe para resolver nuestro problema de investigación.

El problema de esta investigación era identificar la función que tiene la metáfora en la argumentación de El Príncipe, en el momento de abordar algunos problemas políticos sobre los cuales el autor florentino teoriza con extensión en su obra. Mediante la teoría de la metáfora de Paul Ricœur afirmamos que el papel de la metáfora en el discurso de Maquiavelo es el de transmitir con claridad una serie de pautas de orientación práctica que están enunciadas en forma llana antes de cada metáfora, pero que requieren ser ampliadas por el recurso imaginativo que implica la comprensión metafórica. Las metáforas maquiavelianas permiten comprender un concepto político en términos de otro, como sucede en el caso de la perspectiva artística, las cualidades de la zorra y el león o el blanco de un arquero. Estos conceptos ajenos al mundo político le permiten al texto expandir los límites con los que habitualmente se trabaja en el mundo político, según el caso de las metáforas estudiadas, mediante la importancia de la perspectiva en política, las aptitudes para el gobierno certero y la imitación histórica como pauta segura para la acción política. 
Al dejar propuesta la posibilidad de considerar un campo teórico a través de otro, la metáfora ayuda a reinterpretar el significado de un concepto político replanteando o incrementando las bases desde las cuales es posible actuar en política. Sin embargo, la inclinación práctica de las metáforas en El Príncipe están dadas por su contexto argumentativo, ya que éste permite al autor explicar una idea abstracta a través de términos conocidos. Mediante las metáforas en EI Príncipe se formaliza el conocimiento que Maquiavelo desea transmitir, ya que una vez que se ha dejado abierta la comparación entre distintos campos del conocimiento, esta asimilación se mantiene en el tiempo y es susceptible de ser re-interpretada por futuros lectores. La enunciación metafórica proyecta un tipo de idea, que el lenguaje descriptivo o literal no puede explicar, la metáfora es una especie de proceso a través del cual se da a entender más de lo que se describe, y desprenden consecuencias interpretativas no previstas por su autor. La metáfora, entonces, al ser leída, aumenta la capacidad que tiene un lector de imaginar una situación, ampliando el campo del conocimiento sobre ésta, para referirse de forma indirecta, y responder en forma novedosa a situaciones que se presentan en la realidad.

Por lo tanto, una vez que una relación inusitada es imaginada o leída, esta se convierte en una regla de interpretación para la vida del lector, de modo que este es afectado por el excedente de sentido que la obra desea transmitir. Es decir que El príncipe al contener figuras de estilo, de las cuales solo se hace uso cuando el lenguaje ordinario, no permite la descripción de problemas complejos. Por esto se hace necesario recurrir a la creación de un sentido más allá de la descripción literal, y esto se logra sólo a través de la violación regulada de reglas del lenguaje con la finalidad de dar a entender algo más allá de lo que se intenta describir: la metáfora. Que cuando es interpretada, se dirige a la descripción de la realidad de manera indirecta por medio de la suspensión del discurso ordinario de la realidad. Este ejercicio llevado a cabo por la imaginación, brinda una nueva forma de entender un aspecto de la realidad. La paradoja de esta función metafórica, es que desde el recurso de la imaginación que permite forjar la ficción, la metáfora puede re-describir los campos prácticos de la experiencia humana $\varphi$

\section{Referencias}

Betancur, M. (2006). La metáfora y el ver como. Manizales: Editorial Universidad de Caldas.

Cassirer, E. (1996). El mito del Estado. México: Fondo de Cultura Económica.

De Grazia, S. (1994). Maquiavelo en el Infierno. Bogotá: Norma.

Gaillé, M. (2011). Maquiavelo y la tradición filosófica. Buenos Aires: Nueva Visión. 
Horkheimer, M. (1995). Historia, metafísica y escepticismo. Barcelona: Altaya.

Kant, I. (1989). Critica de la razón pura. España: Taurus.

Maquiavelo, N. (1998). El Príncipe. Madrid: Alianza Editorial.

Maquiavelo, N. (2004). Discursos sobre las décadas de Tito Livio. Buenos Aires: Editorial Losada.

Pochat, G. (2008). Historia de la estética y la teoría del arte. Madrid: Akal.

Ricœur, P. (1991). Del texto a la acción: Ensayos de hermeneutica II. Buenos Aires: Fondo de Cultura Económica.

Ricœur, P. (2003) The Rule of Metaphor: The creation of meaning in language. Toronto: Routledge \& Kegan Paul.

Samamé, L. (2010). Una aproximación a la concepción maquiaveliana de historia. Ideas y valores, (143), 123-135.

Skinner, Q. (1985). Los Fundamentos del Pensamiento Político Moderno. México D.F: Fondo de Cultura Económica.

Skinner, Q. (2008). Maquiavelo. Madrid-México: Alianza.

Viroli, M. (2000). La sonrisa de Maquiavelo. España. Tusquets Editores.

Weber, M. (2007). La ciencia como vocación, la política como vocación. Madrid: Espasa.

\section{Cibergrafía}

Palma, P. (2005). El desarrollo de las ciencias a través de las metáforas: un programa de investigación en estudios sobre la ciencia. Revista CTS, 2(6), 45-65. Recuperado de http://www.scielo.org.ar/pdf/cts/v2n6/v2n6a03.pdf

Ricœur, P. (1978). The Metaphorical Process as Cognition, Imagination, and Feeling. Critical Inquiry, 5(1), 143-159. Recuperado de http://www.jstor.org/ stable/1342982. 